\title{
La exigencia retórica in utramque partem y el tema del escepticismo. Algunas reflexiones sobre Razones públicas de Andrés Rosler
}

\author{
The Rhetorical Requirement in utramque partem and \\ the Topic of Skepticism. Some Reflections About Public \\ Reasons by Andrés Rosler
}

\begin{abstract}
Guillermo Lariguet ${ }^{*}$
Carnéades había logrado la tarea hercúlea de liberar nuestras mentes de ese "monstruo salvaje alborotado", que es la aserción. ${ }^{1}$

Se trata, como sabes, del antiguo método socrático de disertar rebatiendo la argumentación del interlocutor, pues Sócrates pensaba que así podía descubrir más fácilmente lo que es más verosímil. ${ }^{2}$
\end{abstract}

Recepción de la propuesta: 09/08/2018

Evaluación y aceptación: 10/09/2018

Recepción y aceptación final: 13/02/2020

Conicet, CIJS (UNC), UNL, Argentina. Correo electrónico: gclariguet@gmail.com. Agradezco, en primer lugar, a Manuel Tizziani por sus comentarios a una versión anterior de este trabajo. Una siguiente versión fue discutida ampliamente en el Workshop sobre Razones Públicas de Andrés Rosler, Río Ceballos, Córdoba, durante los días 26 y 27 de julio de 2019. Conservo un sentido de gratitud para los presentes en el "club de la pelea" de dicho Workshop. Empezando por Rosler, debo también mencionar a Rodrigo Sánchez Brígido, Federico Arena, Juan Iosa, Paula Hunziker, Eduardo Rinesi, Julio Montero, Mariano Garreta Leclercq, Hernán Bouvier y Luciano Venezia. Sus comentarios me ayudaron a pensar mejor. Finalmente, a Eliseo Lariguet, Alejandro Berrotarán, Lucas Misseri y Ramiro Moyano, por su inestimable ayuda en la edición de la versión final.

1 Bett, R., "La ética en el escepticismo antiguo", Dudas filosóficas. Ensayos sobre escepticismo antiguo, moderno y contemporáneo, J. Ornelas y A. Cíntora (compiladores) México, DF, Gedisa, 2014, p. 53.

2 Cicerón, M.T, Tusculanas, Madrid, Alianza, 2010a, p. 83, párrafo 8. 
Resumen: Considerando el libro de Andrés Rosler, Razones públicas, en este trabajo me centro en la naturaleza del debate político en el modelo republicano romano clásico. Reconstruyo cuáles eran las bases histórico-filosóficas que aquel debate tenía en las reflexiones de Cicerón. Sostengo que el requisito retórico in utramque partem se vinculaba con el escepticismo débil antiguo de los académicos Arcesilao y Carnéades. Posteriormente, dicho escepticismo mutó a uno de tipo fuerte en la obra de Pirrón y Sexto Empírico. A continuación, muestro las conexiones de esta clase de escepticismo con la teoría política y moral contemporánea. Más adelante, expongo lo que denomino un escepticismo en materia política. Cambiando el estilo profesoral del trabajo, presento ejemplos contemporáneos de la política argentina a fin de identificar lo que llamo escenarios escépticos matrix. Una de las tesis que defiendo es que la epoché indefinida es imposible, así como la ataraxia plena, ambas son problemáticas de admitir en un campo, como el político, dirigido a la resolución de problemas.

Palabras clave: Debate, Requisito in utramque partem, escepticismo débil y fuerte, política.

Abstract: Considering Andrés Rosler's book, Public Reasons, in this paper I attempt to focus on the very nature of political debate about the model of the classical Roman republic. In order to accomplish this goal, I reconstruct which were the historical-philosophical bases that this debate had in Cicero's reflections. I argue that the rhetorical requirement in utramque partem was linked to the ancient weak skepticism of academics Arcesilau $\mathrm{s}$ and Carneades. Subsequently, I hold that this type of skepticism mutated towards a strong type in the work of Pyrrho and Sextus Empiricus. In the next step, I try to show the connections of this kind of skepticism with contemporary political and moral theory. Moreover, in the following lines, I attempt to explain what I call a political skepticism. But, changing the professorial style of my paper, I present contemporary examples of Argentine politics in order to identify what I call skeptical matrix scenarios. One of the theses that I want to defend is that the indefinite epoché is impossible, as well as full ataraxia, both are problematic to admit in a field, such as the political, directed to the resolution of problems.

Key words: Debate, In utramque partem requirement, weak and strong skepticism, politics. 
La exigencia retórica in utramque partem y el tema del escepticismo...

\section{Yendo al grano}

La teoría republicana clásica que Andrés Rosler defiende está definida por 5 rasgos conceptuales positivos (o sea, los que el republicanismo debe tener) y un rasgo negativo (lo que el republicanismo no debe tener). Los rasgos positivos son: Libertad, Virtud, Debate, Ley, Patria. El rasgo negativo es, como no podía ser de otro modo, el Cesarismo. En lo que sigue, la sección 2, quiero concentrarme en un punto específico. Concretamente, me detendré en el tercer rasgo identificado por el autor para caracterizar al republicanismo: me refiero al "debate". Debo aclarar que no hablaré del debate toto genere, sino de un aspecto que, para Rosler, como para retóricos clásicos como Cicerón, eran medulares al buen debate, a saber: que el mismo sea el trasunto de una disputatio in utramque partem. O sea, una disputa donde cada debatiente ve "las dos caras" de un asunto sobre el que se constata desacuerdo. Para hacer mis consideraciones, voy a emplear dos tipos de herramientas. En primer lugar, en la sección 3, una herramienta más bien histórica que supondrá de mi parte un breve examen histórico por las obras pertinentes de Cicerón, abogado de la disputatio in utramque partem. Sostendré, en la sección 4, que la interpretación adecuada del requisito in utramque partem blandido por el Arpinate conlleva una forma de escepticismo débil. En segundo lugar, en la sección 5, treparé del análisis histórico a una altura mayor para examinar, analíticamente, una posible deriva escéptica fuerte respecto de la exigencia retórica in utramque partem. O sea, en esta sección, presentaré un escepticismo de carácter fuerte que resulta relegado por Cicerón, así como por Andrés Rosler. Alegaré, en la sección 6, que hay algunos escenarios "matrix", que podrían dar pábulo a una forma escéptica fuerte en materia política. Una nota metodológica: en esta sección, cuando pase a los "ejemplos" de escepticismo fuerte el tono de mi trabajo cambiará ligeramente. Pasaré del tono "profesoral” del filósofo político, estilo anglosajón, que prefiere los experimentos mentales, las descripciones definidas o ejemplos reales del "pasado". Saldré de la zona de confort para ofrecer, en un estilo de periodismo filosófico, ejemplos con "nombre y apellido", del "presente", de tal modo que el/la lector/a pueda identificarlos como parte de los problemas de su comunidad política real. 
Esto mismo lo hacía Cicerón en su defensa de la República ${ }^{3}$. Lo dicho no obsta a que los ejemplos que propugnaré tengan la suficiente capacidad de erigirse en tipos ideales útiles, por lo tanto, para describir o caracterizar casos semejantes.

Promediando el final del trabajo, mostraré las razones prácticas por las cuales mi simpatía filosófica está del lado del escepticismo débil y no del fuerte. Debido a la fuerza filosófica turbulenta que encierra el escepticismo fuerte, hay razones conceptuales y prácticas, propias del ámbito político, que indicaré oportunamente, que hacen por lo menos más apetecible al escepticismo débil y certifican, a su tiempo, la versión ciceroniana del requisito retórico in utramque partem en la que se apoya la reconstrucción de Rosler. De todos modos, como también insinuaré, posiblemente haya "trazos" de escepticismo fuerte en materia política que no puedan eliminarse del todo, especialmente en franjas de tiempo que, analíticamente, llamaré tiempo $\mathrm{t} 1$ a tiempo $\mathrm{t} 2$.

\section{El debate republicano según Andrés Rosler}

Rosler defiende un republicanismo clásico (emblemáticamente, Cicerón en la antigüedad). La categoría de republicanismo, para Rosler, debe articular -diría yo que, en forma holística, más que lineal- cinco rasgos positivos y uno negativo. La conjunción de los rasgos positivos; vgr., libertad, virtud, debate, ley y patria, apunta a garantizar la máxima libertad posible dentro de un sistema de normas y de una práctica política de convivencia. El modo usual de entender dicha libertad, no es en términos de lo que los libera-

3 El "giro metodológico" de una filosofía "con nombre y apellido", pensada sobre el presente, a una filosofía "sin nombre y apellido", o recostada en el pasado, se dio con los filósofos liberales modernos. Un contra-ejemplo posible podría ser, en nuestra contemporaneidad, el caso de Philip Pettit y su evaluación del grado de republicanismo del gobierno español del ex Presidente Zapatero. Hablar del presente, y usar nombres y apellidos, no amenaza en mi opinión la distancia que necesita el filósofo para hablar. Esa distancia la dan, en simultáneo, el escrúpulo conceptual y el rigor argumentativo. Los filósofos deben perder el temor de Platón, reversionado en el temor de Leo Strauss, o de los clandestinos franceses del siglo XVIII, que lleva a hablarle al lector "entrelíneas". Prefiero por eso una filosofía más exotérica, y menos esotérica. 
La exigencia retórica in utramque partem y el tema del escepticismo...

les clásicos entendieron por libertad, esto es, la libertad negativa -o la no interferencia- sino la libertad como "no dominación". Un republicanista contemporáneo como Philip Pettit ${ }^{4}$ describe con rigor quirúrgico el ideal, señalando lo siguiente:

Quiero mostrar que este lenguaje de la dominación y de la libertad este lenguaje de la libertad como no dominación- está vinculado con la larga tradición intelectual republicana que ha venido moldeando muchas de nuestras más importantes instituciones y constituciones que asociamos con la democracia. Y quiero argüir que tenemos las mejores razones para hacerle un sitio a este lenguaje en la discusión política contemporánea. Pensar políticamente en los términos de las exigencias de la libertad como no dominación nos proporciona una imagen muy rica y convincente sobre lo que es razonable esperar de un estado decente y de una sociedad civil decente.

Rosler, como Pettit, retrocede en la historia intelectual para mostrar que el republicanismo de antaño está vivo aún hoy. Sus fuentes de pensamiento son las de John Pocock y Quentin Skinner. Tal vivacidad contemporánea de una vexata quaestio, la de la "república", se puede entender cuando admitimos, como alguna vez bregó Arthur Danto, que la historia es una narración que considera también al presente del historiador o del filósofo. La vivacidad de estas ideas es confirmada por la idea según la cual el interés en el republicanismo "no es meramente analítico, ni de anticuario".

A continuación, voy a centrarme en mostrar algunos de los argumentos que Rosler presenta sobre el papel importante que el debate desempeña en la teoría política republicana. Una vez presentados estos argumentos, debe quedar claro que para Rosler, como canónicamente para Cicerón, el requisito retórico in utramque partem juega un papel esencial en la articulación política republicana.

Mi objetivo para este trabajo intentará tomar el mencionado requisito, exponiendo un registro histórico-filosófico del surgimiento de la exigencia retórica in utramque partem, particularmente en la retórica del Arpinate.

4 Pettit, P., Republicanismo. Una teoría sobre la libertad y el gobierno, Barcelona, Paidós, 1999, p. 21. 
A posteriori, voy literalmente a "estrujar" el requisito in utramque partem y ver cuánto jugo conceptual puede sacársele, así como qué composición química tiene ese jugo, o si hay partes de ese jugo que no nos gustaría extraer. Comencemos por el modo en que Rosler explicita el papel del debate en la vida republicana. Para los republicanos, dice Andrés Rosler, el debate es esencial como el mejor modo de identificar y resolver conflictos políticos. La nota esencial que debe acompañar a ese debate para Rosler, como argüiré, se basa en el requisito retórico in utramque partem i.e. como una disputa en la cual ambas partes cuentan con argumentos atendibles.

Los debates se anudan en torno a conflictos. El tipo de conflicto político que a Rosler ${ }^{5}$ le parece conceptualmente una premisa aceptable de arranque para el debate es aquel entendido de manera compleja. Por contraposición, un conflicto en sentido "simple" achaca la génesis del mismo a alguna clase de defecto moral o racional de las partes involucradas. El conflicto en sentido complejo, en cambio, surge de entender que el problema radica en el objeto mismo de la disputa y no en los intervinientes en la misma. El ejemplo que proporciona Andrés Rosler ${ }^{6}$ es el de la igualdad. Se trata para él, y tiene razón en ello, de un concepto abstracto que puede ser especificado de formas rivales; o sea, el concepto de igualdad es muy genérico y sus instancias pueden motivar desacuerdos genuinos. La igualdad es solamente una muestra conceptual y podríamos extendernos en varias páginas citando ejemplos de conflicto, y subsecuente desacuerdo, sobre el mejor modo de distribuir bienes educativos, en la discusión de cuál es el mejor fundamento axiológico para un sistema penal, en si la clonación reproductiva debería admitirse, o de cómo establecer límites éticos al mercado. Estos desacuerdos, sin embargo, y este es un aspecto crucial para calibrar la posición de Rosler, no ejemplifican una concepción facciosa de la razón. Podemos estar divididos, pero esto no es igual a facción. Ello es así por cuanto para el republicano la discordia debe tratarse de un modo tal que no maximice el desacuerdo sino la concordia. Tal concepción es la que anida en la célebre imagen del buen gobierno de Ambrogio Lorenzetti. En dicha pintura contrasta la representación diabólica de la discordia, una mujer con un 
La exigencia retórica in utramque partem y el tema del escepticismo...

serrucho en la mano, de la imagen de la mujer que, con un rostro plácido, representa a la concordia. Esa mujer, recuerda Rosler ${ }^{7}$,

...sostiene también un instrumento de carpintería que se usa para nivelar la rugosidad y lograr una superficie lisa, lo cual parece ser un recordatorio de que los ciudadanos deben limar sus asperezas en lugar de acentuar sus divisiones.

La virtud guía el debate; y este debate debe ser juridificado, dice Andrés, en el sentido de que debe ser un debate entre argumentos con pretensiones de validez de jure. Virtud y argumentación, aliadas por el amor a la libertad, deben buscar el choque entre las mejores razones. El otro puede tener razón, yo puedo estar equivocado, sería otra manera de plantear el requisito in utramque partem ${ }^{8}$. La recurrencia del requisito in utramque partem es decisiva para entender la importancia que Rosler le da al ejercicio argumentativo sobre la base de no ocultar, sino más bien poner en primera línea, la presencia del conflicto político. Así, Rosler ${ }^{9}$ cita a Quintiliano en una reflexión elocuente al respecto:

...a veces dos hombres sabios adoptan con justa causa uno u otro punto de vista, ya que se cree generalmente que también si la razón así los condujera, los sabios podrían pelearse entre ellos.

Esa pelea de sabios debe traducirse, en términos operativos, en una argumentación retórica que, según Rosler ${ }^{10}$, exprese la capacidad de argumentar en favor de ambas partes del debate. Esta capacidad no es otra que la que expone el criterio retórico in utramque partem. Por eso, nuestro autor insiste y afirma, en el estilo del académico escéptico Carnéades, (luego volveré a este académico) que:

7 Ibídem, p. 118.

8 Ibídem, p. 119.

9 Ibídem, p. 120.

10 Ibídem, p. 124. 
...las armas de la facundia pueden valer con relación a ambas partes» in utramque partem «, los maestros de oratoria enseñaban a sus estudiantes a argumentar a favor de ambas partes respecto de cualquier cuestión.

La oratoria clásica estaba preocupada por los criterios de corrección argumentativos, así como fiaba en la discusión la búsqueda de la verdad, a partir de identificar, en el disenso, un conjunto de convicciones comunes. A tal punto esto es importante, que nuestro autor ${ }^{11}$ efectúa-en modo enfático- la siguiente reflexión:

La confianza del discurso público republicano en la retórica se debe a que supone que las técnicas de la oratoria están "en una relación no contingente con la promoción de la verdad", por lo cual es casi imposible ornamentar falsedades exitosamente ${ }^{12}$.

La preocupación de Rosler puede explicarse en una obsesión del propio Cicerón ${ }^{13}$ quien, en De la invención retórica, Libro primero, cavila de la siguiente forma:

A menudo, y mucho, he reflexionado conmigo mismo esto: si la riqueza del decir y la suma dedicación a la elocuencia han traído más de bien o de mal a los hombres y las ciudades. En efecto, cuando no sólo considero los detrimentos de nuestra república, sino también recojo en mi ánimo las viejas calamidades de las máximas ciudades, veo que una no mínima parte de las inconveniencias fue introducida por hombres disertísimos, empero, cuando decido buscar de nuevo en los monumentos de la literatura cosas, a causa de la vejez, alejadas de nuestra memoria, entiendo cómo muchas se establecieron, como muchísimas guerras se extinguieron; como firmísimas alianzas e inviolabilisimas amistades se ganaron tanto por la razón del ánimo como más fácilmente por la elocuencia.

11 Ibidem, p. 127.

${ }^{12}$ Unas líneas más adelante, Rosler critica acertadamente la posibilidad de conexión analítica entre técnicas retóricas y verdad. La conexión no puede ser más que contingente.

${ }^{13}$ Cicerón, M. T., De la Invención retórica, México, Universidad Nacional Autónoma de México, 2010b, p. 1. 
La exigencia retórica in utramque partem y el tema del escepticismo...

Es por lo anterior que el Arpinate ${ }^{14}$, sostendrá, más adelante, en sintonía con lo que describí como el pensamiento de Rosler, que:

...la sabiduría sin elocuencia aprovecha poco a las ciudades, pero que la elocuencia sin sabiduría casi siempre estorba demasiado, nunca aprovecha.

También Cicerón muestra la preocupación por la conexión entre retórica y verdad (aunque sea una conexión frágil) cuando en su De Officiis (Sobre los deberes) patrocina explícitamente, en la tónica de Sócrates y Platón, que uno de los primeros deberes es el de la "honestidad" consigo mismo y con los demás ${ }^{15}$. Más adelante Cicerón ${ }^{16}$ sostendrá, en la línea actualizada por Rosler, que "es propio de todo hombre diligente la investigación de la verdad”. Para Cicerón, esa investigación debe permitirnos nada menos que identificar nuestros deberes (de ahí el título de su obra). Y en contra expresamente de Pirrón, sostiene que su error fue no el de disputar sobre los deberes sino el no haber proporcionado un criterio para elegirlos. Como se verá en la próxima sección, esta desmarcación ciceroniana respecto de Pirrón de Elis es crucial para calibrar qué clase de opción metodológica respecto a la razón argumentativa adopta el Arpinate. El problema de Pirrón sería, según Cicerón, que elevaba a rango elevado el desencanto racional supurado por las máximas non liquet (nada es claro) y non potius (nada es preferible).

Estas últimas reflexiones que acabo de levantar son muy importantes para lo que será un tema central en mi contribución: el tema del escepticismo. A diferencia de Pirrón, que era un escéptico extremo, hay acuerdo en la literatura teórica en sindicar a Cicerón como una especie de "escéptico metodológico"17.

${ }^{14}$ Idem.

15 Cicerón, M. T., Sobre los deberes, Madrid, Alianza, 2015, p. 72, párrafo 2.

${ }^{16}$ Ibidem, p. 80, párrafo 13.

${ }_{17}$ Rosler, A., Razones públicas. Seis conceptos para la república, Buenos Aires, Katz, 2016, p. 127 in fine; Pimentel Álvarez, J., "Cicerón: la disputatio in utramque partem", Nova Tellus, Vol. 8, Revista semestral del Centro de Estudios Clásicos, Instituto de Investigaciones Filológicas, México, 1990, p. 195; Lariguet, G., "Una revisión crítica de Dudas filosóficas. Ensayos 
Ahora pues, otro punto fuerte del debate político es que, para Rosler ${ }^{18}$, la doctrina republicana clásica apela a razones públicas que permitan explicar y eventualmente justificar nuestras acciones. Por eso le dedica un magnífico análisis a la tragedia Julio César de William Shakespeare, centrándose en la retórica de Bruto. Bruto, frente a la demanda de Marco Antonio, desarrolla un largo discurso retórico. Sin embargo, nos dice Rosler, se trata de un discurso retóricamente fallido porque ni es bien comprendido en sus pretensiones republicanas (al punto que un esclavo lo aclama como el nuevo César) ni considera -in utramque partem- la postura opuesta debidamente ${ }^{19}$. Si tradujese a Rosler diría que, el discurso de Bruto, es monológico, se podría decir y, en términos psicoanalíticos, plenamente narcisista y por eso fracasa.

Como sea, habiéndome ocupado de algunos elementos del rasgo "debate" en la teoría republicana de Rosler, específicamente conectados con el requisito retórico in utramque partem, mostrando su conexión con las virtudes de la verdad, es hora de avanzar a la siguiente sección. No debemos, sin embargo, perder de vista que el debate es un rasgo que se refuerza con los otros. El debate, al buscar la verdad, pretende ser funcional al valor de la libertad como no dominación, tal como lo expuse al citar a Philip Pettit.

\section{Un breve recorrido histórico por Cicerón, la disputa in utramque partem y el escepticismo débil}

Ya tuve oportunidad de mostrar que Cicerón es una de las fuentes importantes -no la única desde luego- de influencia intelectual en la concepción

sobre escepticismo antiguo, moderno y contemporáneo, Diánoia, Vol. 60, №. 75, México, 2015, p. 132.

${ }_{18}$ Rosler, A., op. cit., p. 147 y ss.

${ }^{19}$ Digo con mucha audacia porque, como sabemos, Cicerón admiraba las condiciones morales e intelectuales de Bruto y creía que era una esperanza para la República en contra de los planes de César. Inclusive, en Cicerón, M.T., El Orador, Madrid, Alianza, 2017, pp. 52, 33, 34, 35, Excursus 1, dedica la obra a Bruto y hay en Orator varios excursos destinados a elogiar a quien fuera discípulo del retórico griego Pámenes (Cicerón, ibídem, 2017, pp. 87; 105). Ni qué decir que, también, sobre la historia de la oratoria y sus modelos teóricos, Cicerón escribió otra obra anterior a ésta, con el nombre que Rosler fustiga: me refiero a Brutus. 
La exigencia retórica in utramque partem y el tema del escepticismo...

republicana clásica que es foco de atención y defensa por parte de Rosler. Pero, lo que es más urgente enfatizar, es que Cicerón es el defensor de la disputatio in utramque partem. Se trata de un requisito de racionalidad que su retórica emplea, y que Rosler pondera de manera sostenida, para pensar el debate político; un debate que no puede ser endógeno, solo con los que -por lo que sea- ya estamos de acuerdo sino de un debate, como el propio Rosler, dice, exógeno, incluso con los que apoyan diversas formas clásicas -o contemporáneas- de cesarismo.

Ahora bien, ¿cómo valorar filosóficamente la naturaleza del principio in utramque partem? Una respuesta la proporciona el propio Andrés Rosler cuando señala que Cicerón era un "escéptico metodológico"20.

La imagen común que tenemos del escepticismo es la de quien, como dice el Premio Ezequiel de Olaso, el filósofo Manuel Tizziani ${ }^{21}$, "cierra los ojos a las luces de la razón". Sin embargo, para el lector impaciente ruego que se serene. Hablar de "luces de la razón" es una imagen reconociblemente moderna o ilustrada. Y no está mal que así lo sea. Pues, como bien señala Fernando Bahr ${ }^{22}$, Cicerón es un filósofo antiguo cuya obra sobrevivirá al período romano, pasando por la edad media e hincando sus pies en la discusión epistemológica y teológica moderna. Acertadamente, Fernando Bahr recuerda que, en sus Cuestiones académicas, Cicerón se plantea una pregunta audaz y es la de si Dios puede engañarnos, o sea, presentarnos como verdadero aquello que es falso. Una pregunta que, como bien sabemos, permite explicar algunas de las modulaciones de las Meditaciones metafísicas de René Descartes.

La pregunta recién formulada por Cicerón es una pregunta con un cierto tono escéptico. Tiene razón entonces Rosler cuando indica que Cice-

${ }^{20}$ Indudablemente, el predicado "metodológico" es parte de una lectura no muy Oxbridge, de un autor antiguo, en este caso Cicerón, pero, sin embargo, aquí la daré por válida. Válida por cuanto permite entendernos - hoy-acerca de qué clase de escepticismo estaba en juego en Cicerón.

${ }^{21}$ Tizziani, M., "Cerrar los ojos a las luces de la razón: la representación del pirronismo en la Mémoire de Meslier", Skepsis, Revista de filosofía, $\mathrm{N}^{\circ} .17,2018$ a, pp. 26-41.

22 Bahr, F., "Descartes, Bayle y el escepticismo académico. A propósito de una objeción de Cicerón”, Ingenium. Revista electrónica de Pensamiento Moderno y Metodología en historia de las ideas, 2016, pp. 29-42. 
rón era un escéptico metodológico; metodológico por cuanto el Arpinate se vale de la duda, de la confrontación de posiciones, propia del requisito in utramque partem, precisamente para llegar a la verdad. Y, como expresé con mis citas de Cicerón tomadas del Orador, para el Arpinate la investigación está exigida por la búsqueda de la verdad.

Cuando se habla de escepticismo, no obstante, no resulta muy diáfano lo que se quiere decir. Y, por ende, no es cristalino en qué lugar dicha calificación deja parado a Cicerón.

Comenzaré por sostener que Cicerón era un escéptico que, siguiendo a la literatura estándar, denominaré escéptico en "sentido débil"23. Esta denominación puede emerger una vez que hemos confrontado algunos de los principales textos ciceronianos sobre la materia. Este sentido débil, que ya explicaré, se vincula analíticamente con el requisito retórico in utramque partem. ¿Por qué es un sentido débil? Para entender eso hay que caer en la cuenta que Cicerón es un crítico parcial del estoicismo griego; estoicismo que había introducido en Roma, entre otros, Panecio de Rodas. Empero, Cicerón no es un crítico total del estoicismo. Ello por dos motivos que ahondan en el perfil filosófico del Arpinate. Primero porque, si uno relee, por ejemplo, Tusculanas se aprecia bien que Cicerón admiraba varias de las virtudes morales estoicas, i.e., el auto-control, la moderación, el no volcar nuestras expectativas en un mundo externo sobre el que tenemos poco, si acaso alguno, control, así como virtudes como la piedad, la honestidad, etc. Segundo porque Cicerón, como romano que se precie de tal, no toma las doctrinas filosóficas como mónadas que haya que defender aislada y enconadamente. Su tarea de filósofo, guiado por un propósito más bien práctico, de servir a Roma, consistirá en combinar distintas partes de teorías filosóficas: desde la teoría platónica, la peripatética del Estagirita (que para él es el Príncipe de la filosofía), epicúrea, estoica, etc.

Hay un tramo conceptual de la teoría estoica que, no obstante, a Cicerón no le parece convincente. Y ese tramo se vincula con la epistemología estoica. Para dicha epistemología, los objetos externos del mundo, por

${ }^{23}$ Por ejemplo, Román Alcalá, R., "La Academia de Platón: el inicio del escepticismo moderado y su desaparición", Ámbitos. Revista de estudios en ciencias sociales y humanidades, $\mathrm{N}^{\circ} .28,2012$, pp. 29-38. 
La exigencia retórica in utramque partem y el tema del escepticismo...

ejemplo, la mesa que tengo al frente, o el pájaro que veo posado en el fresno de mi jardín, son representados en forma cataléptica. La palabra "katalépsis" remite esencialmente al concepto de "aprehensión mental" o, mejor aún, de percepción. Lo que los estoicos querían decir es que tales, aprehensiones perceptuales, vía las representaciones mentales de las mismas, podían ser verdaderas ofalsas con certeza indubitable. Verdaderas si captaban el objeto externo tal como era; falsas si captaban un objeto -inexistente- o la captación era distorsionada respecto de un objeto existente. Tenemos que comprender, sin embargo, que la discusión que plantea Cicerón sobre esto se recuesta en algunos filósofos griegos que él conocía por lecturas o por diálogos con filósofos de su propio presente. La postura de Cicerón podría calificarse, técnicamente hablando, de "anti-dogmática".

El dogmatismo, por oposición, era el conjunto de doctrinas que consideraban al corpus platónico como orientado hacia una episteme incuestionable. Recuérdese que, a la muerte de Platón, se sucedieron diversos directores de su Academia. El primero será su sobrino Espeusipo (algunos como Alfonso Reyes conjeturan que Aristóteles se enfadó con esto, esperando ser él el elegido). Segundo, en las diversas sucesiones de directores de la Academia, esta fue ocupada por diversas orientaciones filosóficas. Una de ellas fue llamada "escéptica" y se identifica con la dirección de Arcesilao y Carnéades. Ambos son tildados de escépticos en sentido débil o metodológico pues no cuestionaban de manera tajante la posibilidad de aproximarse a algo "verosímil”. Por lo demás, eran filósofos que entendían que el propio corpus platónico encerraba dosis sanas de escepticismo, vía la importancia que Platón le concedía, también, a la dialéctica, la duda y la discusión. O, si se prefiere otra forma de decirlo, a la importancia que tendrá, dentro del corpus platónico, la aporética. En ese momento, quienes más se identificaban con la parte dura, o dogmática de Platón, eran los estoicos Zenón y Crisipo.

Arcesilao se hará famoso por su tesis de lo "razonable", o sea, de que debemos inclinarnos a creer aquello que cuente con la evidencia más convictiva; con lo cual, Arcesilao, es un antecesor de la noción clásica de evidencia empírica. Sin embargo, creer razonablemente que "x", que mi escritorio está frente a mí, o que veo un pájaro en el fresno de mi jar- 
dín, no dejan de ser "aspectos", pareceres. Carnéades, en vena semejante, empleará el término "probable"; de allí que hay que creer, prima facie, lo que resulte más probable creer. Ni lo razonable, ni lo probable son la verdad con mayúsculas; pero estos filósofos no dicen que la verdad sea un absoluto imposible conceptual. Decirlo, los convertiría, estrictamente hablando, en dogmáticos negativos.

Tanto Arcesilao, como Carnéades, buscaban oponer argumentos (utramque partem, otra vez) a un conjunto de argumentos dogmáticos como los que suministraban los estoicos en su interpretación dogmática de Platón. Es decir que aquí había una lucha entre escuelas acerca de cuál era la más legitimada, filosóficamente, para seguir adelante con la herencia de Platón. Y los primeros en idear magistralmente la idea de oponer a un argumento otro argumento, y generar la duda, fueron los escépticos. Cicerón había leído a ambos. Además, había estudiado a Filón de Larisa, un escéptico que afirmará que, en vez de dos academias, la dogmática, y la escéptica, hay una sola, la que hace, si se me permite un giro rawlsiano, equilibrio reflexivo entre las partes dogmáticas y dialécticas del corpus platónico. A Filón lo sucederá su discípulo -también conocido por Cicerón- Antíoco de Ascalón que, de manera furiosa, embate contra su maestro y vuelve a una doctrina estoica dura que enfatiza el carácter más dogmático del corpus platónico.

El Arpinate es consciente de esa lucha de escuelas y del recurso de "oponer argumentos"; un recurso que se hará una marca típica en todo el escepticismo, sobre todo, en el escepticismo -que llamaré fuerte- de Pirrón de Elis y Sexto Empírico. La práctica de oponer argumentos, será un recurso clásico, además, heredado a la modernidad y por eso Montaigne lo usará, con mayor o menor sigilo, en sus ensayos. ${ }^{24}$ Por ejemplo, en esa línea de oponer argumentos, se cuenta que Carnéades, cuando fue hablar a Roma por una multa que debía pagar Grecia, un día habló en favor de la justicia, y al día siguiente, con romanos boquiabiertos, habló en contra. Un día habló de la justicia como valor universal, de tipo "natural”, y al otro día sostuvo que la justicia era relativa pues solamente se reducía a "convencio-

${ }^{24}$ Tizziani, M., Ante el desafío de vivir con otros. Controversias en la prehistoria de la tolerancia moderna: Castellion, Bodin, Montaigne, Santa Fe, Ediciones UNL, 2018b, capítulo IV. 
La exigencia retórica in utramque partem y el tema del escepticismo...

nes sociales"25. La idea de guiarse por convenciones sociales será seguida a pie juntillas por un escéptico metodológico de la modernidad como Descartes ${ }^{26}$ quien, en su Discurso del método, tercera parte, pone sobre la mesa un concepto genial de moralidad: la moral provisional, algunas de cuyas máximas se pintan de este modo:

Por la primera me obligaba a obedecer las leyes y costumbres de mi país y a permanecer en el seno de la religión que Dios permitió me enseñaran en mi infancia. Mi conducta debía ajustarse a la de los varones prudentes de entre todos los que me rodearan; la segunda máxima de mi moral consistía en emplear en mis actos la mayor energía y firmeza de que fuera capaz y seguir las opiniones dudosas, una vez aceptadas, con la constancia con la que seguiría las más evidentes...

Se interpreta que el choque de argumentos sobre el concepto de justicia que narré con respecto a Carnéades, era parte de una jugada que no apuntaba a erosionar un concepto como el de justicia per se, sino a mostrar que era preciso dudar y debatir racionalmente sobre nuestras diversas posiciones. Por eso hablo de escepticismo débil o metodológico y esta es la clase de filosofía que Cicerón recepta, tal como se aprecia con la cita de Tusculanas que efectué en el epígrafe. Y no sólo en Tusculanas disputationes. Por ejemplo, en su Naturaleza de los dioses, Cicerón ${ }^{27}$ usa la idea de verosimilitud y su consabido recurso al utramque partem cuando reflexiona de este modo:

La mayoría ha dicho que los dioses existen, como es lo más verosímil y como todos concluimos, bajo la guía de la naturaleza. Protágoras dijo que él lo dudaba; Diágoras de Melos y Teodoro de Cirene pensaron que los dioses no existen en modo alguno.

25 Se podría sostener que el germen del escepticismo, o uno de cierta clase, es el propagado por los sofistas. Por caso, recuérdese que Gorgias, en el Encomio a Helena, ya anticipa el choque entre argumentos escépticos: Helena era habitualmente vituperada con argumentos no contestados; el encomio de Gorgias, contrabalancea las críticas.

${ }^{26}$ Descartes, R., Discurso del Método, México, Porrúa, 2016, pp. 17-18.

27 Cicerón, M.T., Sobre la naturaleza de los dioses, Madrid, Gredos, 1999, p. 70. 
A tal punto este escepticismo era débil, incluso se podría decir sano, que, tanto Arcesilao, como Carnéades, o Filón de Larisa, sostienen que, no obstante, las dudas, hay que desarrollar nuestra acción según lo más conveniente de acuerdo a convenciones sociales ampliamente aceptadas. Para decirlo con un tono aristotélico, se podría decir que para los escépticos débiles las convenciones pueden ser endoxa, o sea conocimiento respetable prima facie. Tal es la influencia de estos autores en Cicerón que, éste, en Sobre los deberes, nos impele, en caso de duda, a recurrir a las personas más experimentadas.

El escepticismo débil de Cicerón, o Rosler, posibilita articular el debate político con la virtud, el disenso con la búsqueda de criterios correctos para desacordar. La duda no es un detergente corrosivo de la razón, es solo un paso para abrirse camino entre lo más verosímil. Esta conceptualización debe ser guardada en su mente por el lector porque la retomaré al final de este trabajo para evaluar, nuevamente, el aporte de Rosler atinente al nexo entre escepticismo y política.

\section{El escepticismo fuerte clásico y contemporáneo}

Como ya anticipé, existe un escepticismo fuerte y este es, en la antigüedad, el de Pirrón de Elis o Sexto Empírico. Un elemento común con el escepticismo en sentido débil es el uso de la epoché, de la suspensión del juicio que hace el sabio frente a una duda no saldada por evidencia verosímil o probable. Tal suspensión, en ambos tipos de escepticismo, es una manera de indiferencia frente a las dudas que nos turban; puede derivar ${ }^{28}$, por esto, en una forma de ataraxia, o tranquilidad espiritual. Pero hasta aquí llega lo que hay de común entre ambos tipos de escepticismo. El escéptico fuerte no define nada. Su campo es lo indeterminado, lo complejo. Y por eso el escéptico fuerte "nada dice".

${ }^{28}$ Hay discusiones en torno a si esa conexión entre epoché y ataraxia es causal o no. La tesis estándar es que la conexión es contingente ("fortuita", dirían los antiguos); sin embargo, Bolzani, R., "El surgimiento del escepticismo en la Academia: Arcesilao", en Dudas filosóficas. Ensayos de filosofía antigua, moderna y contemporánea, J. Ornelas y A. Cíntora (compiladores), México, Gedisa, 2014, p. 121, piensa que es causalmente necesaria en los pirrónicos. 
La exigencia retórica in utramque partem y el tema del escepticismo...

Uno de los testimonios escritos y más sistemáticos sobre el escepticismo fuerte es el que nos brinda Sexto Empírico. Allí el requisito argumentativo in utramque partem adquiere un tono sombrío. Ya no consiste -como en el sentido débil- en considerar otras razones atendibles, o balancear razones opuestas. Es mucho más serio lo que está implicado, pues el juego de oposiciones revela lo indeterminado: ambos argumentos opuestos vuelven los temas indecidibles. Sexto Empírico ${ }^{29}$, aborda esa oscuridad, por ejemplo, de esta manera:

$\mathrm{Y}$ en absoluto tomamos a proposiciones contrapuestas como afirmación y negación; simplemente como a proposiciones enfrentadas. Y llamamos equivalencia a su igualdad respecto a la credibilidad o no credibilidad, de forma que ninguna de las proposiciones enfrentadas aventaje a ninguna como si fuera más fiable.

La noche más oscura, podría decir un anti-escéptico, ha llegado para la razón. Ya no se trata de un escepticismo metodológico à la Cicerón. Desde la mirada pirrónica, el requisito in utramque partem está infectado de cierta indecibilidad: ambas posiciones son igualmente creíbles o no creíbles; ninguna de ellas aventaja -por más fiable- a la otra. O sea, no se cumple el tibio consejo de Arcesilao o Carnéades, en suma, de Cicerón, por decantarse por lo más verosímil o probable.

En sus Esbozos pirrónicos Sexto Empírico enuncia 10 tropos que explican esta situación agobiante de "impasse" (equipolencia o isostheneia, decían los antiguos) entre opciones contrapuestas. Por ejemplo, el segundo tropo trata de las diferencias según los hombres. O sea, tenemos diferentes modos de percibir y encuadrar los fenómenos; ergo, no hay representaciones catalépticas uniformes como los estoicos propugnaban, ya que, para usar un argumento contemporáneo, no tenemos contactos causales fiables con las cosas. Estos modos diferentes se consagran en múltiples juegos de oposiciones donde es imposible determinar el crédito de cada opción. Algo por el estilo, en el campo moral, sostiene en la contemporaneidad John Mackie cuando, en orden a plantear su escepticismo moral, mantiene que es falso que haya "hechos" que hagan verdaderas o falsas nuestras proposi-

29 Sexto Empírico, Esbozos Pirrónicos, Madrid, Gredos, 1993, p. 54, párrafo 10. 
ciones morales. Otro escéptico contemporáneo fuerte como Walter Sinnot Armstrong ${ }^{30}$ sostiene que los choques entre teorías morales, por ejemplo, nos llevan a pensar que no hay manera exitosa de justificar nuestras creencias. Usted puede plantear un ejemplo, dice Sinnot Armstrong, que lleve agua al molino del deontologismo y, prontamente, se puede identificar de manera no espuria un contraejemplo de utilitarismo del acto y así sucesivamente en una espiral. Esa espiral en la que chocan argumentos muestra que la razón, diría yo, se ha salido de sus goznes. Pues el suelo feraz requerido, de la propia razón a través de su criteriología, o de la retórica argumentativa si se prefiere, deja de suministrar la simiente adecuada para determinar qué argumento es el más correcto.

A los ya referidos diez tropos, tomados en préstamo de Enesidemo, Sexto Empírico agrega otros cinco, tomados de Agripa ${ }^{31}$. Los tropos de Agripa son los que permiten explicar mejor el carácter de "fuerte" con el que etiqueto al escepticismo de Sexto Empírico. Los primeros dos tropos introducen la duda epistémica de qué razones tenemos para creer que $\mathrm{x}$; por ejemplo, el primer tropo de Agripa -que luego llevará a la isostheneia o equipolencia de alternativas- es el que parte de constatar algo que le preocupa mucho a Rosler y los republicanos: el dato del desacuerdo. El segundo tropo es el de la "relación con algo", o sea, la relación que mediaría entre un sujeto que quiere conocer y determinados objetos externos. Aquí la duda está en si los "perceptos" reflejan fidedignamente el objeto exterior o bien, si captan un estado mental propio del perceptor, o si, en rigor, captan alguna clase de relación entre ambos. Ambas situaciones epistémicas (la del desacuerdo y la percepción del mundo exterior) pretenden conducir a la isostheneia que llamo paroxística, o sea, a la equipolencia de alternativas; en definitiva, a la irresolubilidad de una cuestión.

Los últimos tres tropos son los que forman el célebre "trilema de Agri-

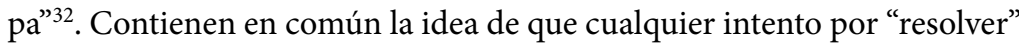
las dos preguntas epistémicas introducidas por los dos primeros tropos,

${ }^{30}$ Sinnot Armstrong,W., Moral Skepticisms, Oxford, Oxford University Press, 2006, p. 112 y ss.

${ }^{31}$ Sexto Empírico, Esbozos Pirrónicos, Madrid, Gredos, 1993, pp. 158-159.

32 Curiosamente, no toda estructura dilemática compleja lleva al escepticismo fuerte. Por ejemplo, el famoso "cuatrilema del consecuencialismo" de Nino, C., (Doxa, Cuadernos de Filosofía del Derecho, $\mathrm{N}^{\circ} .4,1987$, pp. 365-366) pretendía desacreditar firmemente al con- 
La exigencia retórica in utramque partem y el tema del escepticismo...

esto es, quién tiene razón en un desacuerdo, o qué es lo que percibimos, caen en un bochornoso fracaso. Ello es así porque o bien recaemos en argumentos ad infinitum, o bien hacemos hipótesis que no podemos demostrar certeramente, o bien recaemos en una forma de circularidad viciosa.

La manera de pensar de Pirrón, de Sexto Empírico, de Sinnot Armstrong en la contemporaneidad, contraviene el fin que Cicerón -o que Rosler- habían querido asegurar para la retórica argumentativa. Un modo que sirva para determinar racionalmente las opciones -en este caso políticas- a seguir. Se trata de una forma mentis que también teóricos del Derecho como Neil MacCormick habían seguido de cerca. En efecto, MacCormick ${ }^{33}$ utiliza, tácitamente, sin nombrarlo, para el caso del Derecho, el requisito in utramque partem, pero ahora en sentido débil, cuando afirma:

El Derecho es una disciplina argumentativa. Cualquier cuestión o problema sobre el que se piense, si es planteado como una cuestión o problema jurídico, exige una solución o respuesta en términos de una proposición que parezca correcta o al menos defendible, aunque preferiblemente concluyente, como cuestión de Derecho. Para comprobar si es correcto o genuinamente defendible o quizás incluso concluyente pensamos en los argumentos que podrían alegarse en favor de la respuesta o solución propuesta. Podemos examinar tales argumentos construyendo todos los contraargumentos que se nos ocurran. Si esto vale para una de las partes de la discusión, debe valer también para la otra. Al reflexionar sobre lo que parece ser el argumento o argumentos más fuertes de una de las partes se comprueba la fortaleza de los argumentos de la otra. $\mathrm{Al}$ resolver el caso contrario hay que enfrentarse con y, si es posible, derrotar a los abogados que logren presentar sus argumentos en su mejor forma posible.

O sea, podemos, dice el autor escocés, construir contrargumentos (utramque partem) pero para determinar cuál proposición es más fuerte. Un choque de argumentos con esta esperanza de identificar la postura más

secuencialismo y entronizar firmemente -no en forma escéptica- al deontologismo moral o jurídico.

33 MacCormick, N., "Retórica y Estado de Derecho", Isegoría, N.21, Madrid, 1999, p. 6. 
defendible no se verifica en los tropos de Sexto Empírico. Algunos han pensado que esta clase de escepticismo fuerte, de haber existido, habría sido una enfermedad práctica como la que Diógenes Laercio describe, no exento de picardía, respecto del propio Pirrón. Un filósofo que, por su fuerte escepticismo, vivía en apuros prácticos, una y otra vez. Por ejemplo, Diógenes Laercio ${ }^{34}$, al referirse a Pirro o Pirrón, nos dice:

Era consecuente con esto en su vida, sin desviarse ni tomar precauciones ante nada, enfrentándose a cualquier cosa, a lo que le saliera al paso, tanto carros, como precipicios y perros, con total inadvertencia de sus sensaciones. Sin embargo, le ponían a salvo, según dicen los seguidores de Antígono de Caristo, sus amigos que le acompañaban.

Richard Bett ${ }^{35}$ sostiene, respecto de la situación de los "puntos contrapuestos" en la filosofía pirrónica o la de Sexto Empírico que:

Ambos puntos indican la falta de compromiso teórico de los pirrónicos. "Igual fuerza" es una noción psicológica. No es que uno llegue a la conclusión de que la suspensión del juicio le sea «requerida racionalmente». Más bien, uno simplemente se encuentra igualmente atraído -o quizás igualmente repelido- por las opciones presentadas y puesto que uno no puede dejar de ver estas alternativas como mutuamente excluyentes, uno no puede dejar de comprometerse con cualquiera de ellas ${ }^{36}$.

La suspensión del juicio del escéptico, dice Bett, ${ }^{37}$ ...se mantiene gracias a un flujo constante de argumentos e impresiones opuestas y la forma de vida de los escépticos se centra alrededor de asegurar la continuación de este flujo.

${ }^{34}$ Diógenes Laercio, Vidas y opiniones de los filósofos más ilustres, Madrid, Alianza, 2013, p. 534 , párrafo 62.

35 Bett, R., op. cit., p. 59.

${ }^{36}$ Es la situación del asno de Buridán. Puesto a igual distancia entre dos pilas exactamente idénticas de heno, es incapaz de decidir hacia cuál de las dos inclinarse y termina muriendo de hambre. 
La exigencia retórica in utramque partem y el tema del escepticismo...

La línea de Pirro-Sexto Empírico ha conformado el ala dura del escepticismo fuerte actual. En ésta, sobresale Robert Fogelin con su Pyrrhonian Reflections on Knowledge and Justification ${ }^{38}$. Como explica acertadamente Modesto Gómez Alonso ${ }^{39}$, Fogelin cuestiona que: 1. Podamos atribuirle el mérito del "acierto" al sujeto epistémico; 2. Que alguna vez ejerzamos competencia epistémica en nuestra agencia.

Los escenarios pirrónicos de Fogelin son de errores no eliminados, aunque eliminables. Sin embargo, cuando se introduce la posibilidad de la eliminación del error, se cae, este es el argumento fuerte de Fogelin, en un invariable "regressus ad infinitum". La idea motriz de Fogelin es que al introducir cada vez nuevos elementos, nuevas pruebas, dichas pruebas exigen nuevas comprobaciones para eliminar posibilidades y así indefinidamente. Para volver al ejemplo que di páginas atrás sobre creer que " $x$ ", que veo un pájaro sobre el fresno de mi jardín; podría no ser un pájaro lo que veo (aunque, como diría Gettier una creencia me justifica a creerlo). Podría ser, por ejemplo, un mecanismo robótico. Pero, al examinarlo, tampoco es claro que sea un mecanismo robótico, pues podría ser un dispositivo bio-mecánico, y así hasta el infinito.

En su discusión de la estrategia anti-escéptica de Timothy Williamson, el filósofo mexicano Jorge Ornelas ${ }^{40}$ defiende que la tesis escéptica fuerte consiste en advertirnos que no podemos saber nunca, realmente, cuando estamos frente al escenario epistémico bueno o al escenario epistémico malo. El argumento escéptico puede construirse, señala Ornelas, de este modo:

$1 \mathrm{E})$ No sabes que no estás en un escenario escéptico (vgr., un mundo matrix)

${ }^{38}$ Fogelin, R., Pyrrhonian Reflections on Knowledge and Justification, Oxford, Oxford University Press, 1994.

${ }^{39}$ Gómez Alonso, M. M., "El neo-pirronismo de Robert Fogelin: estrategias escépticas en la filosofía analítica contemporánea”, en Bordoy, A., Una mirada actual a la filosofía griega, Palma de Mallorca, Ediciones de la SIFG, 2012.

40 Ornelas, J., "E=K y antiescepticismo: algunos problemas para Williamson", en Dudas Filosóficas. Ensayos sobre escepticismo antiguo, moderno y contemporáneo, México: UAM/Gedisa, 2014, p. 288. 
Guillermo Lariguet

2 E) Si no sabes que no estás en un escenario escéptico, entonces no sabes que $\mathrm{p}$ (que hay una chimenea frente a ti)

Por lo tanto:

3 E) No sabes que $\mathrm{p}$ (modus ponens de 1 E y 2 E).

Para ponerle "carne" al esquema formal recién presentado, podríamos, según la invitación escéptica de Jorge Ornelas, suponer que:

Un sujeto S 1 (Descartes, pongamos por caso) se sienta a meditar frente a su chimenea y su experiencia perceptiva de ver una chimenea lo justifica a afirmar que «sabe « que hay una chimenea frente a él. Esta es la manera en que comúnmente describimos la adquisición de justificación perceptiva para nuestras creencias empíricas. Por otro lado, S2 (Gescartes), un Doppelgänger de Descartes, tiene las mismas actitudes hacia las mismas proposiciones y por lo tanto S2 también se sienta a meditar frente a su chimenea y basado en la misma experiencia perceptiva afirma saber que hay una chimenea frente a él. Como suele ocurrir-afirma Ornelas- S1 está en el caso bueno en el que sabe que su experiencia perceptiva es verídica, mientras que S2 está en el caso malo, el escenario escéptico (un mundo matrix, pongamos por caso) en el que S2 no tiene conocimiento, pues su experiencia no es verídica (no hay chimenea realmente frente a él, sino que es el resultado de un software muy sofisticado que alimenta el cerebro de S2).

El problema con lo anterior, prosigue Ornelas, es que:

Aunque es clara la asimetría epistémica entre S1 y S2 en lo relativo al conocimiento (S1 sabe que hay una chimenea frente a él y S2 no), no es claro que ocurra lo mismo con respecto a la justificación que cada uno de ellos tiene; ambos parecen tener exactamente la misma justificación perceptiva ${ }^{41}$.

${ }^{41}$ Hilando más fino, si S1 y S2 ostentan la misma "justificación perceptiva”, entonces tampoco es del todo correcto decir que S1 "sabe que hay una chimenea frente a él". El escepticismo 
La exigencia retórica in utramque partem y el tema del escepticismo...

Pues bien, expuesto el escepticismo en sentido fuerte, en su modulaciones antiguas y contemporáneas, Andrés Rosler podría preguntarme porqué he incluido una digresión sobre el mismo. Está claro, por lo que asumí historiográficamente hablando, que Cicerón era un escéptico metodológico, en sentido débil, en la senda de Arcesilao y Carnéades, o de Filón de Larisa. Entonces, ¿qué papel jugaría el escepticismo en sentido fuerte? Indudablemente un papel conceptual.

El propio Rosler ha admitido que su tarea de reconstrucción de la república clásica no es meramente histórica sino analítica o conceptual. En la mencionada república, el requisito in utramque partem es decisivo para moldear un debate guiado por virtudes morales y cívicas. Sin embargo, desde el punto de vista analítico o conceptual, pero incluso por las razones historiográficas apuntadas, aquél requisito adquiere dos tonalidades bien diferenciadas: o bien una tonalidad débil o metodológica, como es el caso patente de Cicerón, o bien una tonalidad oscura, amenazante, fuerte, como en Pirrón, Sexto Empírico, Fogelin, etc. Quiero sostener que, en este segundo caso, in utramque partem se vuelve isostheneia en un sentido que denominaré paroxístico. En el primer caso, el requisito implica asumir que hay otra razón que puede ser atendible y, por tanto, hay que ejercitar el oficio de la verosimilitud o probabilidad. Pero, en este segundo caso, isostheneia implica que ambas opciones tienen "equal strenght" en forma paroxística y no sabemos hacia dónde inclinarnos. No hay posibilidad de verosimilitud o probabilidad como en el escepticismo débil ${ }^{42}$. Este es el

fuerte debiera implicar lógicamente que no podemos distinguir entre S1 y S2. Eso quiere decir Ornelas, si lo interpreto bien.

${ }^{42}$ Bolzani, R., (op. cit., p. 102) realiza una labor de exégesis de Académicas de Cicerón con el fin de defender que, no obstante, sus diferencias, académicos escépticos, como Arcesilao y Carnéades, y pirrónicos, tienen importantes semejanzas. Ambos tipos de escepticismo, que yo llamé débil y fuerte, comparten la noción de suspensión de juicio, así como la idea de que las cosas están indeterminadas. Pero, como Bolzani (ibídem, pp. 120-121) consigna, existen dos diferencias relevantes que marcan la distinción histórica entre ambas escuelas, y corroboran mi distinción analítica entre dos escepticismos, uno débil, y otro fuerte. Una diferencia es que pirrónicos, como el mismo Sexto Empírico, no creen que se pueda resolver la discordancia equipolente (isosthenès diaphonía) entre proposiciones sobre cosas del mundo. Esto conduce a desistir en buscar una solución y coadyuvaría a la ausencia de perturbación del sabio (ataraxia). Segundo, a distancia de Arcesilao que no creía imposible la aprehensión de los objetos, los escépticos pirrónicos sí. 
caso más genuino para ejercitar la suspensión del juicio y para desistir de dar una solución, desembocando así, si todo van bien, en una genuina ausencia de perturbación anímica en el sabio (ataraxia). Pero, ¿podemos hacer tal cosa en el ámbito político? Algunos creen, por principio, que tal epoché es más fácilmente realizable en el campo epistemológico; i.e., creencias perceptivas, por ejemplo, como las de la cita de Jorge Ornelas. Pero tal cosa sería descabellada en el ámbito político, o moral, ámbitos prácticos en los que hay algo así como lo que el finado Bernard Williams llamaba "un impulso a la acción”. Pero las cosas no son tan sencillas como las planteo. Y por esto, en la próxima sección, me explayaré en el punto desde una mirada conceptual y ya no con ingredientes históricos. O sea, asumiré, por mor de la argumentación, un rol más Oxford, si se quiere, que Cambridge.

\section{Un tema para el análisis conceptual: in utramque partem y escepticismo fuerte}

Como se ha podido apreciar hasta ahora, Rosler se encolumna detrás de clásicos como Arcesilao-Carnéades-Cicerón, pero no en la línea de Pirrón, Sexto Empírico o Fogelin. Así, Rosler es, en nuestro presente, un partidario de tomar el corpus Socrático-Platónico como guía, pero una guía no enteramente dogmática, sino dialéctica, débilmente escéptica.

Quiero adelantar desde ya, para despejar dudas al respecto, que me resulta más simpático -psicológicamente hablando- el escepticismo débil que el fuerte. Empero, sé que no debo constreñirme a mis estados mentales en primera persona. Sino que la perspectiva personal debe mutar de psicológica en filosófica: o sea, a la tercera persona. Es por esto preciso que examinemos el escepticismo fuerte, especialmente en política, el campo de interés de Rosler. Y tasar porqué el mismo tendría algunos elementos que un filósofo debería explicitar y discutir. Sobre todo, para no caer en lo que, transmutando el ámbito primario de interés de Rosler, el político, podría llamarse un "cesarismo filosófico". Debemos poder, si no contestar, al menos considerar algunos elementos potencialmente disruptivos como los acarreados por un escepticismo fuerte. 
La exigencia retórica in utramque partem y el tema del escepticismo...

Antes que nada, se impone una reflexión metodológica como la siguiente: aunque los temas explícitos del escepticismo sean epistemológicos, implicaría un non sequitur sustentar que lo epistémico y lo político (o lo moral) son sustancias sin conexión. Al contrario, lo epistémico y lo político, las razones para creer y las razones para actuar, mantienen conexiones diversas. Quien plantea esto claramente, con relación al ámbito político y su vínculo con la discusión escéptica en materias epistémicas, es John Christian Laursen ${ }^{43}$ en su conocido trabajo "Escepticismo y política" en el cual sostiene lo siguiente:

El escepticismo es parte de una gran familia de palabras que se refieren a la teoría del conocimiento o la epistemología. La epistemología es la teoría sobre qué conocemos, cuándo y cómo. Una manera útil de entender y clasificar las ideas políticas es distinguirlas por su estatus epistemológico. Qué conocemos, cuándo y cómo tendrá un efecto sobre lo que podemos justificar y lo que podemos criticar en política.

Ahora bien, cuando se habla de escepticismo y política, o de escepticismo "en la política", salta a la vista que nuestros contemporáneos no usan el término "escéptico" en política como lo pensaban los antiguos citados (ni los que respaldan un sentido débil, ni los que hacen lo propio con un sentido fuerte). Insistamos en que los antiguos hablan de "epoché". Pero los contemporáneos acostumbran a utilizar la palabra escepticismo en un sentido reflejado por la obra The audacity of hope de Barak Obama ${ }^{44}$, en la cual él recuerda, al respecto, que:

«[Cuando me preguntan] “ipor qué quieres entrar en algo sucio y asqueroso como la política?” ... usualmente sonrío, muevo la cabeza afirmativamente y digo que entiendo el escepticismo...».

${ }^{43}$ Laursen, J. C., "Escepticismo y política", Revista de Estudios Políticos, Madrid, 2009, p. 125.

${ }^{44}$ Citado por Laursen, ibídem, p. 124. 
Es decir, la vulgata contemporánea subyacente al empleo del término, supone las actitudes doxásticas y conativas que refieren a temas como la desconfianza sistémica o el desgano generalizado de ciertos sectores sociales frente a "todos" los políticos. Por ejemplo, la frase argentina recurrente en boca de mucha gente cuando profiere que "todos -los políticos- son iguales” presupone este sentido de la palabra escepticismo. Un sentido peligroso para la democracia siempre que aceptemos, previamente, que sin política no podemos ni debemos vivir. Y todas las implicaturas conversacionales que podemos, incluso, extraer de esta aceptación.

Alguien podría sostener, y quizás valga la pena pensarlo en contra de la aserción de Laursen, que la gente de hoy, después de todo, usa el término, en forma análoga, a como lo hacían los antiguos; o sea, que esta desconfianza o desgano son la cara presente de la suspensión del juicio. Con seguridad que algo análogo, no idéntico, hay cuando traducimos ese desgano o desconfianza en una falta de emoción por involucrarse de algún modo con lo público, con la política. Es decir, tal carencia de pathos político podría desembocar en la apatía. Esa falta de pasión (de pathos por la política) podría, quizás, reconvertirse, a posteriori, en una forma de suspensión del juicio. Pero, sin embargo, no es, estrictamente hablando, una suspensión porque la gente afirma algo: dice que "todos los políticos son iguales", o sea, estrictamente, no suspende el juicio.

He sugerido, y vuelvo a insistir en ello, que probablemente chirríe en nuestros oídos filosóficos hablar de suspensión del juicio en el ámbito político. La política demanda acción, como bien lo ha descripto Hannah Arendt en La condición humana. Y hay, como sostuve líneas atrás, una suerte de impulso a la acción del que hablaba el finado Bernard Williams cuando pensaba en un mundo práctico vecino al político como el de la moralidad.

No obstante, quisiera, a continuación, indicar algunos elementos inquietantes que podrían sugerir que el mundo político, por lo menos a veces, podría ser similar al mundo matrix al que aludí con las citas a mi colega mexicano Jorge Ornelas. Cuando hablo de escenarios políticos matrix estoy empleando una metáfora y, por esto, se impone una precisión conceptual preliminar. Lo que quiero dar a entender con escenarios polí- 
La exigencia retórica in utramque partem y el tema del escepticismo...

ticos matrix es bastante amplio y cubre diversas formas de estar "enchufados" a datos falsos y, o bien no saber que es así, o bien experimentar dudas insolubles como la que explica la isostheneia que llamé paroxística y, entonces, no sentirnos capaces de afirmar o negar nada. Las máquinas a las que podemos estar enchufados pueden ser diversas como, por ejemplo, las apariencias políticas, las convicciones que genera la buena o mala retórica de un político, la influencia causal notoria de medios y redes sociales de la des-información, a la existencia de sesgos cognitivos, a la disposición de respuestas emocionales impulsivas, pensamientos desiderativos, etc.

\section{Escenarios matrix en la política, periodismo filosófico basado en algunos ejemplos con nombre y apellido del presente}

Cambiando el estilo profesoral de las secciones anteriores, en lo que sigue, quiero ofrecer ejemplos del presente con nombre y apellido. Lo haré en un estilo más de periodismo filosófico y esto forzosamente cambia algo el tono de las secciones anteriores. Plantearé, algunos escenarios políticos escépticos en sentido fuerte. Consideremos, las siguientes hipótesis:

a) El ámbito político, como dice Hannah Arendt, en La condición humana, es el de la "aparición"; la aparición en público, característicamente, por medio de la palabra, el discurso, es una condición importante de la acción pública. Por esto, la filósofa alemana distingue lo público respecto de lo privado, la acción política, respecto de las labores (nuestras operaciones biológicas de reproducción) y del trabajo. Alguien podría cuestionar esta distinción público-privado, arguyendo que las labores y el trabajo no pueden sustraerse totalmente del campo de preocupaciones de la teoría de la justicia. Por ejemplo, a un marxista le interesaría que el trabajo sea un problema también público, político. $\mathrm{Y}$ a una feminista le interesaría que las labores formen parte de la agenda de una teoría de la justicia. Pero no es esto lo que quiero levantar a discusión aquí, sino centrarme en la idea de "aparecer". La política se mueve con fenómenos que nos parecen de una 
forma. Pero, ¿parecer y verdad política son sinónimos analíticos? O sea, ¿lo que percibimos del teatro político es una representación cataléptica estoica o, al menos, verosímil o probable tal como diría el escepticismo débil de Arcesilao-Carnéades-Cicerón? ¿Cómo podemos distinguir el error de lo cierto, lo verdadero de lo falso en el terreno político ${ }^{45}$ ? Unas palabras de la propia Arendt, en las que convendría no pasar muy rápido, podrían mostrar el problema del aparecer político que estoy insinuando. Ella señala, al respecto que:

La manifestación de quién es el que habla y quién es el agente, aunque resulte visible, retiene una curiosa intangibilidad que desconcierta todos los esfuerzos encaminados a una expresión verbal inequívoca ${ }^{46}$.

O sea, lo que el párrafo citado de Arendt insinúa es claramente diferente del escepticismo débil fundado en un juicio de verosimilitud o probabilidad de lo que aparece. Tales clases de juicios son interpretaciones. Y no es que Arendt sea escéptica, pero su párrafo y su idea de aparición pública, sí permiten esta reflexión. Por ejemplo, recuerdo que, cuando era chico, un político llamado José Corzo Gómez que tenía una columna televisiva sobre los jubilados, siempre golpeaba la mesa, para reafirmar que lo que decía era cierto, y gritaba ¡con las manos limpias! ¡Con las manos limpias! Un término que, posiblemente él no sabía, desnuda un problema clásico de la teoría política que versa en precisar si es posible, cómo y cuándo, evitar que los políticos se ensucien, moralmente hablando, las manos. No recuerdo ahora exactamente, pero luego se desató un problema que lo involucraba en temas de corrupción. Sin embargo, desde un momento t1 a t2, figurativamente hablando, se podría decir que estábamos en una suerte de escenario matrix. Algo semejante a ese relato vivimos a diario los ciudadanos argentinos respecto de lo que creemos "saber" sobre los procesos judiciales a funcionarios del gobierno kirchnerista anterior. $¿$ Distinguimos, realmente, lo verdadero de lo falso? ¿Podemos hacerlo? ¿Hay

${ }^{45}$ Sobre esto véase, Arendt, H., Verdad y mentira en la política, Barcelona, Página Indómita, 2017. 46 Arendt, H., La condición humana, Barcelona, Paidós, 2005, p. 205. 
La exigencia retórica in utramque partem y el tema del escepticismo...

presunciones fidedignas que, por ejemplo, incriminen verdaderamente en algunos actos de corrupción a la ex-presidenta Cristina Fernández de Kirchner en, al menos, algunos de los numerosos procesos judiciales en su contra? Frente a la disyuntiva de creer o no creer en su inocencia respecto de actos de corrupción, ¿no se verifica, al menos en algunas ocasiones no determinables a priori, la isostheneia paroxística de la que hablé líneas atrás? El escepticismo fuerte parece un triste candidato para dar cuenta de nuestra situación epistémica respecto de esta pregunta. Un masivo stock de des-información imprecisa, o deliberadamente imprecisa, que baja de medios y/o redes sociales tiende un velo opalino sobre nuestra percepción política y jurídica. Ese stock, además, se retroalimenta de intereses contingentes, partisanos, de búsqueda de poder nuevo, o de búsqueda de retención de poderes viejos. Nuevamente, este ejemplo, parece un escenario matrix como el esbozado por Jorge Ornelas.

b) Conexo con lo anterior, es preciso remarcar que los medios de información suelen ser los grandes ministerios de la mentira mediáticos. Se instalan a diario, como si fuesen verdades, hechos cuya existencia, al menos desde un tiempo t1 a t2 es imposible saber si existen o si ocurrieron, o si tienen la modalidad crucial con que se los presenta. Algunos pueden ser un tanto risueños. Una vez, una colega me pasó una nota que decía que Martha Nussbaum, cuando recibía el doctorado honoris causa en la Universidad de Antioquia, Medellín, gritó un improbable ¡viva Perón! No siempre disponemos de colegas colombianos que puedan certificar si esto es así. Y, suponiendo que los hubiera, ¿escucharon bien? Otro ejemplo podría ser el reciente "caso" Hebe Vessuri, destacada etnógrafa argentina, exiliada en Venezuela, durante la última dictadura militar argentina. Académica de renombre internacional, Vessuri, tiene una jubilación venezolana (que hoy, por la situación económica de aquel país es como no tener nada). Como investigadora, de rango principal en Conicet, estuvo contratada, por aquel organismo. Algunos kirchneristas, en redes sociales, difundieron la alarmante noticia de que el ministerio de modernización del presidente Macri la había "despedido". Luego de arduos chequeos de información, pude comprobar que, en rigor, no renovaron su contrato en forma lícita: 
Hebe Vessuri tiene 76 años y es perfectamente entendible no renovarle su contrato. Aunque, por supuesto, su situación sea crítica desde el punto de vista económico dada su magra jubilación venezolana. Los macristas, por su lado, difundieron, por todos lados, la noticia de que el actual candidato a la presidencia de la nación por la nueva coalición kirchnerista (el apodado frente "todos"), Alberto Fernández, no era, desde hacía 18 años, profesor de derecho penal en la Universidad de Buenos Aires. Inclusive mi peluquero, un día, mientras me afeitaba, me lo dijo encolerizado. Tuve que hacer varios cruces de datos para llegar a la conclusión de que la noticia era falsa. Alberto Fernández, según comunicados oficiales de la propia universidad de Buenos Aires, sigue dictando la materia. El hecho de que, en los casos comentados, haya podido separar lo verdadero de lo falso, hablaría de un escepticismo débil, más que fuerte. Pero no todas las personas (más bien son pocas) son las que pueden cruzar datos, dudar, ponderar. Por ello, al menos, desde un tiempo 1 a t2, parecemos envueltos en las sombras de otra matrix o escenario político escéptico fuerte.

c) Lo anterior autoriza a descolgar la cuestión de la popularmente llamada "post-verdad". El prefijo "post" evoca un deterioro, entre otras cosas, de la búsqueda de evidencia empírica. La gente "certifica" la verdad en narraciones. La habilidad del/a escritor/a para contar una historia sustituye, por imperium absoluto, las credenciales que portan los hechos mismos. Así, por ejemplo, era usual hace unos años hablar del "relato kirchnerista" 47 respecto de los progresos sociales, económicos y culturales logrados. El gobierno que rige actualmente el país, mientras esto escribo, utiliza frondosos relatos de progreso tales como que "atraeremos inversiones fructuosas", que "habrá brotes verdes en la economía", que se invierte en ciencia "más que en el gobierno anterior”, etc. El ciudadano común, con poco tiempo para reflexionar, puede, sin saberlo, sin nombrarlo así, estar en un escenario matrix. No tiene por lo general chances de acceder a datos objetivos o de entenderlos en caso de acceder a los mismos. Y ello por definición, pues el valor epistémico de la verdad ha sido sustituido por otras cosas que valen

47 Sobre el papel de los relatos (míticos) en el populismo, véase el estudio de Casullo, M. E., ¿Por qué funciona el populismo?, Buenos Aires, Siglo XXI editores, 2019, p. 47 y ss. 
La exigencia retórica in utramque partem y el tema del escepticismo...

más. En el entretanto, que va de $\mathrm{t} 1$ a t2, no sabemos, no podemos afirmar ni negar nada. El escepticismo fuerte puede ser como un Elfo que se presenta refulgentemente bello y bondadoso, ocultando con su máscara, la existencia de un señor oscuro que se llevará consigo cualquier criterio que nos permita discernir lo verdadero de lo falso.

d) Desde hace ya varios años, las neurociencias están cobrando una inusitada notoriedad, a veces bien ganada, a veces exagerada, a veces con resultados interesantes, a veces con experimentos conceptualmente débiles. Sin embargo, algo que está bastante probado es la existencia de "sesgos cognitivos". John Rawls, sin ser "neurocientífico", hablaba de algo no idéntico, pero semejante, al referirse a las "cargas del juicio". Estos sesgos de los que hablo (por ejemplo, los confirmatorios) están a la orden del día. Permítaseme ahora la licencia de hablar en forma "estereotipada": Alguien de "derecha” en Argentina suele leer Clarín (si es laico), Nación (si es católico). Si es más "progre" lee Página 12 o el Cohete a la luna de Horacio Verbitsky. Esto podría explicarse en los términos, para seguir con la imagen de las neurociencias, de Joshua Greene cuando habla de la existencia de "tribus morales"48. Una tribu busca lo que refuerza su identidad interna y repele lo que la amenaza. El muy neoliberal lee Clarín, pero no Página 12. El kirchnerista extremo puede leer sólo Página 12 pero puede experimentar vómitos y/o mareos con Clarín. El ultraderechista cordobés puede ver al Señor Agustín Laje o al Señor Eduardo Feinmann, y el progresista atender solamente a $\mathrm{C} 5 \mathrm{~N}$. La ontología de las tribus morales, de tener un grano empírico de asidero, explicaría la idea de que la democracia se divide en "facciones" que es, justamente, lo que Rosler quiere evitar. Cuando uno se percata de que el conjunto doxástico y conativo de las facciones tiene costras duras, imposibles de remover con argumentos, puede surgir la sospecha de otro escenario matrix como los estudiados por Jorge Ornelas. Trasladado el escenario al ámbito de ciertas emociones recalcitrantes, pensemos en el odio puro, también parece imposible cambiar dicha disposición de carácter. Así, por ejemplo, están los que “odian a la yegua”, donde esta

${ }^{48}$ Greene J., Moral Tribes: emotion, reason, and the gap between us and them, Oxford, Oxford University Press, 2013. 
figura de hembra equina remite a la ex- Presidenta Cristina Fernández de Kirchner. La "yegua" es una figura des-moralizante; caemos, así, en lo que la república de Rosler quiere conjurar: oscilar entre el vituperio y la adoración arrobada. Parece que, otra vez, por la ventana, podemos haber ingresado a algo semejante a un escenario matrix.

e) Finalmente, me gustaría señalar uno de los más evidentes escenarios para el escepticismo fuerte. Me refiero al deterioro de la argumentación como tarea racional, para no hablar de la carencia de una retórica elocuente, guiada por la virtud, como la propugnada por Cicerón y a la que ya hice referencia varias páginas atrás. Por ejemplo, el gobierno nacional de Macri ha instalado la técnica sistemática de los "eslóganes" que operan como obstáculos para la reflexividad profunda, de la sensibilidad por los datos objetivos. Inclusive intelectuales formados en el "poder del argumento" suelen repetir "frases" tales como "se robaron medio país" (cuidado: no dicen país entero) para aludir al gobierno kirchnerista anterior. Sin embargo, proferir frases no equivale a una argumentación vis à vis, sobre datos, no realiza una ponderación cuidadosa de elementos en juego, no equivale, entonces, al pulcro ejercicio del requisito in utramque partem ciceroniano, o a una devoción a la verdad, haciendo chocar argumentos, evidencias. Los argumentos, como digo, son reemplazados por eslóganes. No son los tópicos de Aristóteles, posos de sabiduría práctica acumulados, no es la endoxa, son solo frases que operan como el sepulcro de la disputatio in utramque partem; o sea, de la disputa retórica metodológicamente hábil, para mejorar nuestras prácticas políticas, guiados por la búsqueda de lo más parecido a la verdad. En esta obturación de la argumentación racional coadyuva la búsqueda de intereses facciosos, la búsqueda del poder por el poder mismo y, desde luego, una dilatada falta de auto-crítica de unos y de otros.

Los ejemplos que he dado son de nuestra política local; sin embargo, podrían ser ejemplos generalizables a otras sociedades políticas. Por otro lado, los fenómenos conceptuales inquietantes que he presentado no son exhaustivos y cada uno de ellos podría ser analizado con más detalle. Por último, se trata, posiblemente, de ejemplos que presuponen diversas clases de causas del escepticismo en política. Inclusive, se podría decir, no todas 
La exigencia retórica in utramque partem y el tema del escepticismo...

revelan la isostheneia paroxística. Y, más aún, no todos los casos cuenten como escepticismo fuerte sino simplemente débil ya que, una mejora en la información, o un cambio en las disposiciones anímicas, por ejemplo, o un cambio en circunstancias fácticas del orden económico, o una alteración de las actuales relaciones de poder, podrían incidir en que tengamos una clase de escepticismo débil como el propagado por Arcesilao-Carnéades-Cicerón-Rosler. Y no que tengamos un escepticismo matrix que nos lleve a la isostheneia paroxística.

Mi objetivo ha sido emplear los ejemplos para generar escenarios matrix, con una dimensión cronológica (t1-t2); en dicho espacio de tiempo quizás, y digo quizás para insinuar una hipótesis conceptual tentativa, estemos frente a escenarios escépticos -en el campo político- en sentido fuerte. He tomado el recaudo de delimitar temporalmente tales escenarios con cierta cautela conceptual y por eso he hablado, figurativamente, de escenarios de t1 a t2. Esto no debilita esta clase de escepticismo. Pues, como mostré con Fogelin, una de las condiciones analíticas de definición del escepticismo fuerte es que el mismo conviva con escenarios donde hay errores graves no eliminados, aunque eliminables. Los errores no eliminados, para Fogelin, recordemos, pueden tener progresión infinita en ámbitos epistémicos. Además, son errores que no sabemos que no están eliminados. Los mismos pueden tener una existencia corta, mediana o larga y eso se grafica con la simple advocación del tiempo t1 hasta el tiempo t2. Por ejemplo, pensando rápidamente, $\mathrm{y}$ dando un último ejemplo, de un escenario matrix, recuérdense las elecciones a gobernador en la ciudad de Córdoba, Argentina, de 2007, cuando la diferencia entre el candidato Schiaretti y el candidato Luis Juez era de 1.1 porcentuales en el recuento de votos a favor del primer nombrado. Juez denunció fraude; hubo una gran campaña nacional e inclusive marchas "contra el fraude" (dándolo por hecho); marchas que aglutinaron a sectores incluso diversos del "defraudado" Juez y, sin embargo, nunca supimos si hubo fraude; si la diferencia porcentual era un “error". Un sector creyó que hubo fraude, otro no lo creyó; otros vacilaron entre creer y no creer. En un escenario así, lo correcto, epistémicamente hablando, es no usar los dedos de la mano para afirmar o negar que "x", esto es, que hubo fraude. La hipótesis fogeliana de errores eliminables, 
pero que lo serían en un paradójico regreso al infinito, podría también ejemplificarse quizás con algunos de los ejemplos políticos como el dado con el supuesto fraude electoral. O sea, no siempre es necesario referir al escepticismo apelando a los consabidos ejemplos epistemológicos puros.

Si usted quiere otro nombre más cercano para el escenario matrix descrito, con situaciones de isostheneia paroxística, podría hablar de la enorme "opacidad" del poder donde unos actores andan, en ocasiones, a ciegas. Quizás la única afirmación que podamos hacer es que el poder es, por definición, opaco. Y así, no podemos aventurar afirmaciones o negaciones. Otros dirán que no es opaco, o que no es completamente opaco. Pero, ¿cómo sabemos qué parte es opaca y qué parte es transparente? ¿Cómo estamos seguros de los criterios que utilizamos para trazar la distinción entre opacidad y transparencia?

Necesito señalar que, aunque no todos los fenómenos citados antes se dejan domesticar por la categoría de la "mentira política", está claro que varios sí (por ejemplo, las manos limpias de Corzo Gómez). Empero, hubo un tiempo t1 a t2 que no sabíamos que estábamos engañados con Corzo Gómez. La interrupción del engaño, además, es por fuerza, contingente. Si a la difundida mentira le agregamos el acoplado según el cual un político que miente "diga que está diciendo la verdad", añadimos más nafta al fuego: tenemos ahora la paradoja del mentiroso instalada en la práctica política de facto.

Como Cicerón, o como Rosler, y lo he dicho, me siento cercano, por razones psicológicas, y filosóficas, por razones de primera y tercera persona, al escepticismo de corte metodológico o débil. Ello es así, sobre todo, si se considera que asumir la identidad del filósofo puede llegar a suponer la adquisición de algo de lo legado por lo escépticos débiles. El skeptikoi es el que duda. A diferencia del fervor de los "militantes", la duda es una de las marcas de distinción de los filósofos ${ }^{49}$. Solo que en el caso del escepticismo débil esa duda es una forma de lidiar con la complejidad del mundo político, pero no un obstáculo para actuar o para tomar decisiones políticas.

49 Dado que la acción de dudar es una marca distintiva del verdadero filósofo, el escepticismo débil no estaría "tan lejos" del falibilismo del que hablaba en el siglo XX sir Karl Popper. Aunque no son es lo mismo, claro está. 
La exigencia retórica in utramque partem y el tema del escepticismo...

Por esto es que Cicerón fustiga a aquellos que rehúyen completamente de la vida pública ${ }^{50}$.

Si los escenarios matrix que he presentado antes se sostienen, tenemos un enorme problema conceptual y práctico a la vez: la política, conceptualmente, demanda acción, allí donde el escéptico fuerte demanda retirarse a la suspensión del juicio. Esta demanda a la acción responde a un fin práctico: las situaciones de desacuerdo político tienen que poder resolverse razonablemente, de lo contrario la política perdería su fin de administrar inteligentemente el conflicto político. Pero, si esto es así, los desacuerdos, a contrapelo de Sexto Empírico, o Agripa, tienen que ser genuinos. Un republicano actual como Philip Pettit ${ }^{51}$ lo tiene claro cuando, en relación a la existencia política de discursos rivales, afirma que:

Consisten en supuestos compartidos, lo suficientemente abstractos como para permitir las diferencias, y lo bastante afines como para poner restricciones al debate acerca de esas diferencias.

La observación filosófica de Pettit contrasta, como es evidente, con el escepticismo fuerte. La fuente antigua de la concepción escéptica fuerte, como vimos, se retrotrae a Pirrón y, especialmente, a Sexto Empírico, filósofo que sería, al decir de Pierre Bayle, $;$ un antecesor de la filosofía moder$n a !^{52}$ Como se recordará, cuando referí a los cinco tropos de Agripa, que Sexto añade a los de Enesidemo, podíamos figurar que, por ejemplo, ante la situación epistémica de responder quién lleva razón en un desacuerdo - político, a nuestros fines- cualquier respuesta (o tropo) caería en forma irrefragable en un regreso al infinito, a hipótesis indemostrables o a circularidades viciosas. El trilema de Agripa es el que, en mi opinión, instila el escepticismo neo-pirrónico de Fogelin al que ya hice alusión.

Es de todo necesario, sin embargo, que abra aquí un inciso respecto de la incompatibilidad entre el escepticismo -especialmente fuerte- y la

${ }^{50}$ Esta fue la reacción típica de los romanos cultos que se volcaron al epicureísmo en su versión romana; por ejemplo, es el caso de un gran amigo de Cicerón como Ático.

${ }^{51}$ Pettit, P., op. cit., p. 18.

52 Para los contrastes entre Sexto y Descartes, véase Zuluaga, ibídem, 2014, nota a pie 1, p. 154. 
política dado el impulso a la acción que subyace a ésta. Como indiqué en varios tramos de este trabajo, en el escepticismo antiguo débil (Arcesilao, Carnéades, Cicerón) y fuerte (Pirrón, Sexto Empírico), así como en el escepticismo moderno ${ }^{53}$ (Descartes o Montaigne) se destaca la existencia de criterios "para orientarse en la vida". O sea, la imagen de escépticos "tan locos como para dejarse morir", no impulsados por acción alguna, sería falsificable. Sexto Empírico ${ }^{54}$ lo sabía cuándo, en el ya citado Esbozos Pirrónicos, expone cuatro criterios de guía vital. Dice:

Y parece que esa observancia de las exigencias vitales es de cuatro clases y que una consiste en la guía natural, otra en el apremio de las pasiones, otra en el legado de leyes y costumbres, otra en el aprendizaje de las artes. En la guía natural, según la cual somos por naturaleza capaces de sentir y pensar. En el apremio de las pasiones, según el cual el hambre nos incita a la comida y la sed a la bebida. En el legado de leyes y costumbres, según el cual asumimos en la vida como bueno el ser piadosos y como malo el ser impíos. Y en el aprendizaje de las artes, según el cual no somos inútiles en aquellas artes para las que nos instruimos.

La versión de Sexto, indudablemente, contraría la pintura risueña que Diógenes Laercio -oportunamente referido en mi trabajo- hace de la desorientación vital de Pirro. Aún si esta pintura fuese cierta, es indudable la existencia de un patrón conceptual que recorre al escepticismo, desde la antigüedad hasta el presente, que se sintetiza en la clasificación de criterios de orientación de la vida establecidos por la cita de Sexto Empírico ${ }^{55}$. No está aquí exactamente el problema de incompatibilidad entre escepticismo fuerte y política. Reitero: la incompatibilidad conceptual y práctica entre escepticismo fuerte y política recae, como he dicho, en los dispositivos que podrían llamarse epistémico-vitales de suspensión del juicio y búsqueda

${ }^{53}$ Sobre las correlaciones entre la tradición clásica y moderna del escepticismo, véase Bahr, F., Tradición clásica y filosofía moderna. El juego de las influencias, Santa Fe, Ediciones de la UNL, 2012.

${ }^{54}$ Sexto Empírico, op. cit., pp. 23-24.

${ }^{55}$ Los criterios para orientarse en la vida, naturalmente, sirven incluso para seguir nuestras inclinaciones a las verdades "iluminadas por Dios". Por ejemplo, el filósofo francés del 
La exigencia retórica in utramque partem y el tema del escepticismo...

de la ataraxia. Son precisamente estos dispositivos, los que se encuentran sindicados también por el ya citado Laursen ${ }^{56}$ cuando refiere al «auténtico» escepticismo político. Ello es así porque la suspensión del juicio, operada merced al carácter irresoluble de los desacuerdos, o a la imposibilidad de determinar la verdad de los asuntos humanos, se prorroga al infinito, supone hipótesis indemostrables o termina en un círculo vicioso. Cualquier intento de resolver el desacuerdo, o responder preguntas, o establecer un valor de verdad, patina en el terreno siempre aceitoso del trilema de Agripa, ya mencionado.

No tengo espacio, ahora, para articular una objeción completa a dirigir contra el escepticismo fuerte. Ad nauseam, existe una larga historia de contra-respuestas al escepticismo fuerte. Si la isostheneia paroxística estrictamente, implicara antinomias de la razón, el propio Kant en su Crítica de la razón pura, ofrece una solución compleja que pasa, primero, por adoptar algunas ideas incondicionadas que figuran como antinomias y permutarlas en la reserva de ideas regulativas de la razón y, segundo, defender con

siglo XVI, Henri Estienne, traductor de los Esbozos Pirrónicos, sostendrá en el prefacio de la obra, que la relevancia de la misma reside en su carácter de "antiperístasis". O sea, en su rol de "oponer" al dogmatismo religioso de la época un sano escepticismo. Por esta vía, Estienne, como afirma Basílisco, B., "Marine Mersenne, Henri Estienne y el redescubrimiento de las Hipotiposis pirrónicas de Sexto Empírico”, en Bahr, F., Tradición clásica y moderna. El juego de las influencias, 2012, p. 81, introduce un "fideísmo escéptico" que consiste en encontrar a Dios por la fe y no por los argumentos racionales. Estos argumentos racionales, llevados a su máxima expresión, comportan una "glotonería dogmática", eventualmente productora de depresión (como sería el caso del juicio del propio Estienne sobre su salud), que hay que sanar con un escepticismo. Sin embargo, dado que se trata de un fideísmo escéptico, o sea, de la conjunción de fe y escepticismo, Estienne -y otros como él- no podrían aceptar la prolongación permanente de la epoché, característica del escepticismo "fuerte" del que hablo en mi texto. . O sea, el escepticismo entendido como isostheneia o equipolencia, no puede convertirse en un extremo, como lo era el dogmatismo anti-religioso. El escepticismo pirrónico si bien puede usarse como antiperístasis es peligroso si se deja que crezca demasiado. Por eso, el filósofo, matemático y sacerdote, Marin Mersenne, pensador del siglo XVII, creerá que un uso indebido del escepticismo puede también poner en peligro la fe. En su apologética del catolicismo, presente en su obra $\mathrm{La}$ verité de las sciences contre les sceptiques ou pyrrhoniens, luego de mostrar la analogía entre verdad matemática y verdad teológica, presenta al "filósofo cristiano", argumentando contra el lugar común pirrónico, según el cual, la duda radical debe llegar a la imposibilidad de afirmar o negar la verdad de la existencia de Dios (Basílisco, B., ibídem, 2012, pp. 82-83).

${ }^{56}$ Laursen, J. C., op. cit. , pp. 123-142. 
argumentos propios de la razón ideas que no pueden demostrarse, tal como ocurre con el postulado de libertad de la tercera antinomia, argumentada en su Crítica de la razón práctica.

Insisto, a riesgo de ser machacón: el escepticismo fuerte, en materia política, apuntaría sus cañones contra dos cosas importantes: por un lado, contra la posibilidad de resolver temas y desacuerdos políticos; por el otro lado, contra el ideal de verdad. Los escenarios matrix, tomados en serio, parecen volver indecidibles temas y desacuerdos políticos. Legaríamos, por la vía de su admisión, a lo que los griegos, en la antigüedad, llamaban "stásis". El otro punto involucrado en el escepticismo fuerte es el ataque a la posibilidad de verdad alguna. Hablar de verdad política o de verdad en la política, además, presupone complicaciones analíticas. ¿Qué significa hablar de este modo? La respuesta requiere de mucha argumentación y no puedo darla ahora. Pero baste decir que, si no es la verdad el valor central de la política, aunque desde luego que no es el único, sí podamos, quizás, admitir las nociones de verosimilitud de las que hablaba Cicerón. A la larga, quizás, se puedan certificar como "verdades" juicios de verosimilitud y, con ello, se corrobore, para Andrés Rosler, su anhelada conexión no contingente entre la discusión retórica in utramque partem y un stock de creencias verdaderas.

Quiero defender que la epoché indefinida no es el camino, normativamente plausible, para pensar la política. La suspensión del juicio puede ser bienvenida para lograr que los actores políticos sean actores reflexivos, actores exponentes de un punto de vista ampliado como quería el Kant de La crítica del juicio y el Kant de Hannah Arendt. O de actores que eviten, como añoraban los escépticos débiles antiguos, ese "monstruo alborotado" que es la aserción o, diría yo, la irrefrenable necesidad que cierta gente, con o sin preparación filosófica, tiene siempre de "discursear" sobre temas políticos complejos, sin más, sin recaudos reflexivos previos. Con todo, aunque la reflexión demanda la suspensión del juicio, la misma no puede en política prolongarse sine die. Pues, el impulso a la acción del que ya hablé, requiere tomar decisiones, actuar.

La ataraxia, el último perdigón del escepticismo, sí que me parece dudoso moralmente para el recinto político. La ataraxia, la tranquilidad de 
espíritu, no puede conseguirse a cualquier coste moral. En de Officiis Cicerón nos recuerda y describe como esos hombres que se retiran totalmente de la vida pública y se reclinan en sus estudios buscan la tranquilidad de espíritu. Hacerlo, en principio, dice él, si estamos enfermos, por ejemplo, no parece reprobable. Pero si no es así, si no tenemos una buena excusa, desafectarnos completamente de la vida pública parece remover nuestro derecho legítimo a quejarnos. Más aún, nos convertimos en los "filisteos" a los que refería Hannah Arendt cuando pensaba en hombres recluidos en la vida privada, sin afección pública alguna.

La tranquilidad de espíritu, entendida como completo retiro de la vida política, de la vida pública si usted prefiere el término, me parece inmoral cuando cientos de hermanos pasan hambre, frío, tienen miedo al poder y son humillados.

\section{Bibliografía}

Arendt, H., La condición humana, Barcelona, Paidós, 2005.

Arendt, H., Verdad y mentira en la política, Barcelona, Página Indómita, 2017.

Bahr, F., Tradición clásica y filosofía moderna. El juego de las influencias, Santa Fe, Ediciones de la UNL, 2012.

Bahr, F., "Descartes, Bayle y el escepticismo académico. A propósito de una objeción de Cicerón”, Ingenium. Revista electrónica de Pensamiento Moderno y Metodología en historia de las ideas, 2016.

Basílisco, B., "Marine Mersenne, Henri Estienne y el redescubrimiento de las Hipotiposis pirrónicas de Sexto Empírico", en Bahr, F., Tradición clásica y moderna. El juego de las influencias, 2012.

Bett, R., "La ética en el escepticismo antiguo", Dudas filosóficas. Ensayos sobre escepticismo antiguo, moderno y contemporáneo, J. Ornelas y A. Cíntora (compiladores) México, DF, Gedisa, 2014.

Bolzani, R., "El surgimiento del escepticismo en la Academia: Arcesilao", en Dudas filosóficas. Ensayos de filosofía antigua, moderna y contemporánea, J. Ornelas y A. Cíntora (compiladores), México, Gedisa. 
Casullo, M. E., ¿Por qué funciona el populismo?, Buenos Aires, Siglo XXI editores, 2019.

Cicerón, M.T., Sobre la naturaleza de los dioses, Madrid, Gredos, 1999.

Cicerón, M.T, Tusculanas, Madrid, Alianza, 2010a.

Cicerón, M. T., De la Invención retórica, México, Universidad Nacional Autónoma de México, 2010b.

Cicerón, M. T., Sobre los deberes, Madrid, Alianza, 2015.

Cicerón, M.T., El Orador, Madrid, Alianza, 2017.

Descartes, R., Discurso del Método, México, Porrúa, 2016.

Diógenes Laercio, Vidas y opiniones de los filósofos más ilustres, Madrid, Alianza, 2013.

Fogelin, R., Pyrrhonian Reflections on Knowledge and Justification, Oxford, Oxford University Press, 1994.

Gómez Alonso, M. M., "El neo-pirronismo de Robert Fogelin: estrategias escépticas en la filosofía analítica contemporánea", en Bordoy, A., Una mirada actual a la filosofía griega, Palma de Mallorca, Ediciones de la SIFG, 2012.

Greene J., Moral Tribes: emotion, reason, and the gap between us and them, Oxford, Oxford University Press, 2013.

Lariguet, G., "Una revisión crítica de Dudas filosóficas. Ensayos sobre escepticismo antiguo, moderno y contemporáneo, Diánoia, Vol. 60, N . 75, México, 2015.

Laursen, J. C., "Escepticismo y política”, Revista de Estudios Políticos, Madrid, 2009.

MacCormick, N., "Retórica y Estado de Derecho", Isegoría, N.21, Madrid, 1999.

Nino, C., (Doxa, Cuadernos de Filosofía del Derecho, N.4, 1987.

Ornelas, J., "E=K y antiescepticismo: algunos problemas para Williamson", en Dudas Filosóficas. Ensayos sobre escepticismo antiguo, moderno y contemporáneo, México, UAM/Gedisa, 2014.

Pettit, P., Republicanismo. Una teoría sobre la libertad y el gobierno, Barcelona, Paidós, 1999. 
Pimentel Álvarez, J., “Cicerón: la disputatio in utramque partem”, Nova Tellus, Vol. 8, Revista semestral del Centro de Estudios Clásicos, Instituto de Investigaciones Filológicas, México, 1990.

Román Alcalá, R., "La Academia de Platón: el inicio del escepticismo moderado y su desaparición", Ámbitos. Revista de estudios en ciencias sociales y humanidades, $\mathrm{N}^{\circ} .28,2012$.

Rosler, A., Razones públicas. Seis conceptos para la república, Buenos Aires, Katz, 2016.

Sexto Empírico, Esbozos Pirrónicos, Madrid, Gredos, 1993.

Sinnot Armstrong,W., Moral Skepticisms, Oxford, Oxford University Press, 2006.

Tizziani, M., “Cerrar los ojos a las luces de la razón: la representación del pirronismo en la Mémoire de Meslier", Skepsis, Revista de filosofía, $\mathrm{N}^{\circ} .17,2018 \mathrm{a}$.

Tizziani, M., Ante el desafío de vivir con otros. Controversias en la prehistoria de la tolerancia moderna: Castellion, Bodin, Montaigne, Santa Fe, Ediciones UNL, 2018b.

Zuluaga, M., "Escepticismo pirrónico-escepticismo cartesiano", Dudas filosóficas. Ensayos sobre escepticismo antiguo, moderno y contemporáneo, J. Ornelas y A. Cíntora (compiladores) México, DF, Gedisa, 2014. 